\title{
Original paper \\ The Early Cretaceous volcanic activity in the western part of the Gobi-Altay rift (Shiliin Nuruu, SW Mongolia)
}

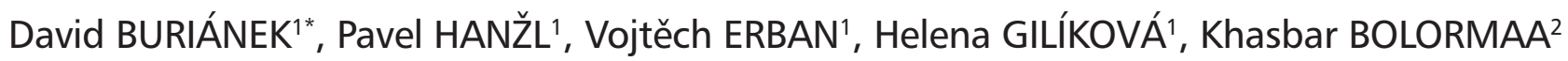 \\ ${ }^{1}$ Czech Geological Survey, Klárov 3, 11821 Prague 1, Czech Republic; david.burianek@geology.cz \\ ${ }^{2}$ Geological Investigation Center, Songino Khayrkhan District, PO Box 37/307, Ulaanbaatar, Mongolia \\ * Corresponding author
}

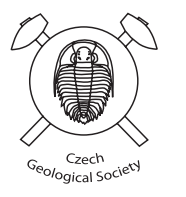

The Cretaceous continental sedimentation in SW Mongolia was commonly accompanied by volcanic activity. Bimodal association of the Cretaceous Khulsan Gol Formation is represented mostly by calc-alkaline and rare alkaline volcanic rocks (basaltic andesite, trachybasalt to trachyandesite lavas or tuffs with lahars). The lavas were extruded mainly subaerially, although locally there is a subaqueous component present corresponding to final phases of Mesozoic sedimentation in the Gobi-Altay rift zone. Variations in chemical and isotopic composition reflect crustal assimilation coupled with fractional crystallization of parental magma generated by melting of lower lithosphere and/or uppermost asthenospheric mantle. These within-plate volcanic rocks can be explained as initial stages of Cenozoic magmatic activity in the Mongolia.

Keywords: Cretaceous; calc-alkaline volcanites; Gobi-Altay; Sr-Nd isotopes; petrogenesis; Mongolia Received: 8 April 2008; accepted 11 June 2008; handling editor: E. Jelinek

The online version of this article (doi: 10.3190/jgeosci.026) contains supplementary electronic material.

\section{Introduction}

Volcanic activity in Mongolia has continued almost without interruption for the past $160 \mathrm{Ma}$, being concentrated within two periods, namely the Early Mesozoic and the Late Mesozoic-Cenozoic (Yarmolyuk and Kovalenko 2001).

The Early Mesozoic (Triassic-Early Jurassic) igneous period was largely influenced by continental collision during the closure of Mongolsk-Ochotsk marine basin (in the NE part of today's Mongolia). System of troughs infilled with terrigenous, coal-bearing molasse developed during the Triassic-Jurassic (Yanshin 1976) and they are interpreted as foreland basins. However, relations to strike-slip faulting could not be excluded (Hendrix et al. 1996). Extensional tectonics was accompanied by Early Mesozoic granitoid intrusions in eastern Mongolia. The only terrigenous sediments of this age are preserved in western Mongolia (Yarmolyuk and Kovalenko 2001).

Late Mesozoic-Cenozoic igneous period was related to extensional tectonics, which is one of the most striking features in the $\mathrm{N}$ and NE parts of the North China Block and the S part of the Variscan Central Asian Orogenic Belt (e.g. Hendrix et al. 1992). Foreland-style basins (Graham et al. 2001), rift zones (Yanshin 1976), system of grabens and graben-synclines were formed in the Late Mesozoic times (Late Jurassic-Early Cretaceous). The tectonic depressions formed the sites of formation of lava plateaux, as well as volcanic ring structures and subvolcanic intrusions composed of rhyolites, granitoids and basaltoids (Yarmolyuk and Kovalenko 2001).

The end of the Early Cretaceous saw the progressive cessation of tectonic processes throughout the whole of Mongolia and the Late Cretaceous-Palaeogene is a period of development similar to a platform evolution (Yanshin 1976). Within-plate magmatic activity in the southwestern Mongolia started during Mesozoic and culminated in the Cenozoic (Barry et al. 2003). The majority of the Late Mesozoic volcanic rocks tend to be localised within the Gobi-Altay rift (Yarmolyuk 1986). The Gobi-Altay rift zone can be divided into three segments: eastern, central and western, which to some extent differ in their subsequent history of magmatism. Eastern segment is Late Jurassic to Middle Cretaceous, central one is Late Jurassic to Late Cretaceous and western is Early to Late Cretaceous (Yarmolyuk and Kovalenko 2001).

Numerous basaltic lava sheets and body of lahar with prevailing acid fragments (rhyolite, granitoids) belonging to the western part of the Gobi-Altay rift zone are well exposed in the area of Shillin Nuruu and Khar Argalantyn Nuruu Mts. They are part of the Upper Jurassic to Lower Cretaceous continental sediments preserved in the separate block along the southern rim of Valley of Lake west of the Boon Tsagaan Nuur, Gobi Altay Aymag (SW Mongolia).

The interpretation of textural features in the Late Cretaceous volcanic rocks, their close relation to palaeontologically dated sediments, as well as newly obtained 
whole-rock geochemical and isotopic data contribute to understanding of the origin of volcanic rocks in the intracontinental rift environment.

\section{Geology}

The Upper Jurassic-Lower Cretaceous sediments west of lake Boon Tsagaan Nuur are exposed along the southern margin of intermontane depression Ulaan Shalyn Khooloi, which separates the Neoproterozoic to Lower Palaeozoic complexes of the Lake Zone in the south from the Proterozoic metamorphic rocks of the Byadrag Terrane in the north.

Most of the Upper Mesozoic sequences in the area are exposed in a flat syncline in the Shiliin Nuruu Mts. and at Samoadanba Uul Mt. (Fig. 1). Minor exposures are bound to the slopes of the Erdene Uul Mt. in the west and in surroundings of river Khulsni Gol in the east. The syncline is built by continental sediments and terrestrial volcanic rocks developed in the western part of the Late Mesozoic Gobi-Altay rift zone (Yarmolyuk 1983, 1986; Kovalenko et al. 1995). There are preserved transgressive contacts of Upper Jurassic-Lower Cretaceous sediments with the underlying Precambrian-Palaeozoic sequences. Nevertheless, there are often rather gradual depositional transitions (Fig. 2) between the individual Mesozoic formations (Hanžl et al. 2007): Toromkhon, Undurukhin, Anday Khudag and Khulsan Gol (e.g. Sinica 1993).

The Upper Jurassic Toromkhon Fm. consists of poorly to extremely poorly sorted, usually red conglomerates, breccias and sandy conglomerates. They were interpreted as sediments of proximal part of alluvial fans (Gilíková et al. 2007).

The Lower Cretaceous Undurukhin Fm. was described in the area of the Lake Zone and Mongolian Altay by Ivanov in Rauzer et al. (1987) based on previous studies of the Mongolian Mesozoic basin undertaken by Martinson (1982). The sediments of the Undurukhin Fm. (Berriasian to Valanginian) form cycles up to $13 \mathrm{~m}$ thick consisting of conglomerates grading upwards into sandstones, mudstones and marls. They rest locally unconformably upon the pre-Mesozoic basement. Contact with the Toromkhon Fm. in the footwall is transitional with local wash-outs. The formation was presumably deposited in a fluvial and shallow lacustrine environment

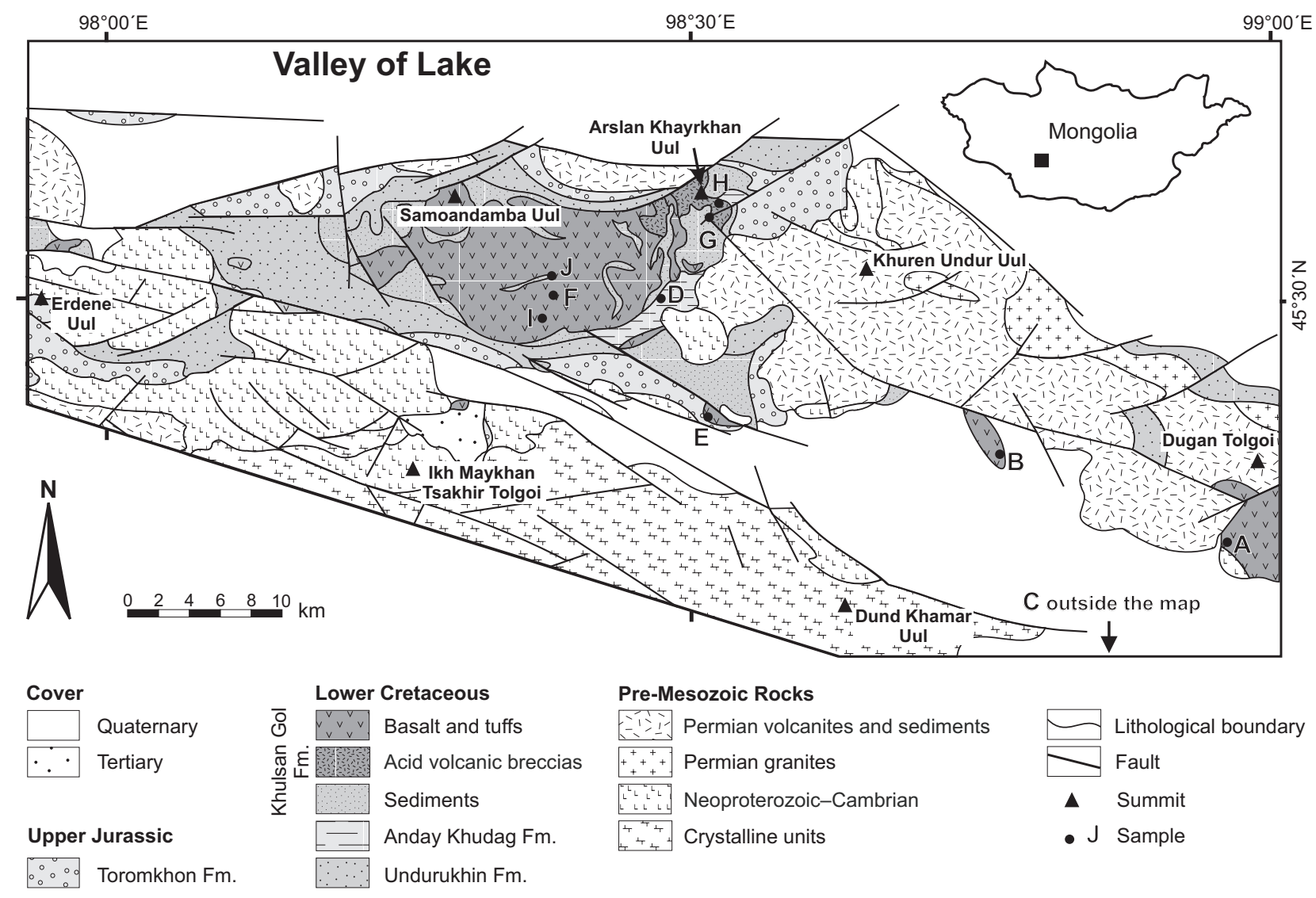

Fig. 1 Simplified geological outline of the Shiliin Nuruu area based on new geological mapping (Hanžl et al. 2007). Geochemical samples labelled by their ID (same as in tables). 


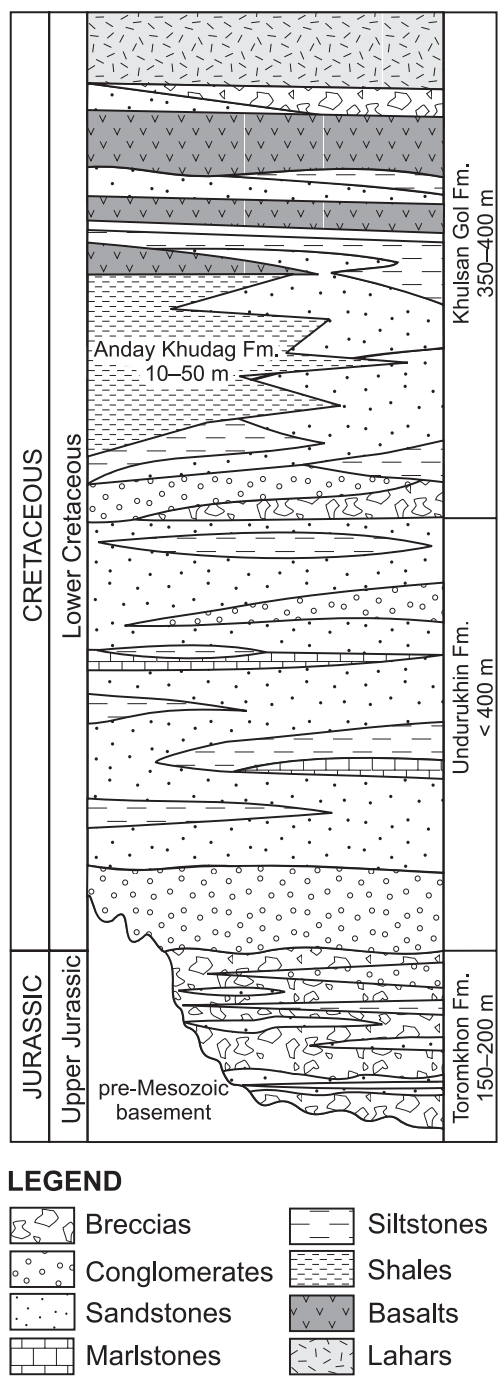

Fig. 2 Summary stratigraphic column for the studied area modified from Hanžl et al. (2007).

(Gilíková et al. 2007). According to petrography, the sediments of the Undurukhin Fm. were derived mainly from Permian volcanic rocks.

The Anday Khudag Fm. (Hauterivian to Barremian) is characterized by variable and commonly small thickness (first tens of metres). The sediments of the formation are mostly exposed as a finer facies (mudstones and siltstones with fine-grained conglomerates and sandstones on the base) inside the Khulsan Gol Formation.

The Khulsan Gol Fm. (Aptian-Albian) has a volcanosedimentary character and represents the uppermost part of the Mesozoic sequence in this segment of the GobiAltay rift. The thickness of the Khulsan Gol Fm. is estimated to $350-400 \mathrm{~m}$ in the area of the Arslan Khayrkhan Uul Mt. The main constituents are sandstones alternating with marlstones and mudstones, accompanied by sporadic intercalations of coal, conglomerates and breccias. Shal- low lacustrine environment is supposed to have prevailed during deposition of the formation; the accumulations of bivalves in the sandstones probably indicate storm events. The conglomerates, breccias, and massive sandstones are sediments of alluvial fan. The most usual direction of the material transport was from north to south. According to petrography, the sediments of the Khulsan Gol Fm. were derived mainly from the Permian volcanic and plutonic rocks. The evolution of the sedimentary basin was terminated by volcanic activity documented by basaltic lava flows and sills with thickness up to 30 meters. Lahar and coarse-grained volcanic breccia layers are composed of acid to intermediate rocks (rhyolite, granitoids). They are up to $100 \mathrm{~m}$ thick and are exposed in the uppermost part of the Khulsan Gol Fm. in the Arslan Khayrkhan Uul Mt. Basalts rarely enclose xenoliths of sediments; mantle and lower crustal xenoliths are missing. Marlstones and mudstones are baked on the contacts with basaltic flow, forming zones only several centimetres thick. No structures similar to a volcano morphology were found in the area; the character of lavas instead resembles plateau basalts.

\section{Analytical methods}

Whole-rock samples were collected in the frame of the Development cooperation project of the Czech Republic "Geological mapping of the Mongolian Altay at a scale of 1:50,000". Nine were sampled in the area of the Shilin Nuruu (Fig. 1); one was located on the SE slopes of the Gichigeney Nuruu Mts. c. $60 \mathrm{~km} \mathrm{~S}$ of the Arslan Khayrkhan Uul.

The only wet major-element whole-rock geochemical analyses performed under standard conditions (Hanžl et al. 2007) at the Central Geological Laboratory in Ulaanbaatar are available for two samples. Eight rock powders were analysed in the Acme Analytical Laboratories, Vancouver, Canada. Major-element contents were determined using ICP ES and trace elements by ICP MS. The whole-rock analyses were interpreted by the GCDkit software (Janoušek et al. 2006).

Strontium and neodymium isotope analyses were performed at the Radiogenic Isotope Laboratory of the Czech Geological Survey. Samples were dissolved using a combined $\mathrm{HF}-\mathrm{HCl}-\mathrm{HNO}_{3}$ attack. Sr and bulk REE were separated by cation-exchange chromatography using BioRad AG-W X8 resin loaded into quartz columns. Nd was further separated on quartz columns with Biobeads S-X8 coated with HDEHP (Richard et al. 1976). Isotopic composition was analysed on Finnigan MAT 262 thermal ionization mass spectrometer in dynamic mode using a double Re filament assembly for both $\mathrm{Sr}$ and $\mathrm{Nd}$. The NBS 987 reference material yielded a long-time average 
${ }^{87} \mathrm{Sr} /{ }^{86} \mathrm{Sr}$ of $0.710244(1 \sigma=0.000013,27$ values $)$, while the $\mathrm{Nd}$ La Jolla average ${ }^{143} \mathrm{Nd} /{ }^{144} \mathrm{Nd}$ was $0.511852(1 \sigma$ $=0.000007,25$ values). The decay constants applied to age-correct the isotopic ratios are from Steiger and Jäger (1977) (Sr) and Lugmair and Marti (1978) (Nd). The $\varepsilon_{i}^{N d}$ values were obtained using Bulk Earth parameters of Jacobsen and Wasserburg (1980).

Electron microprobe analyses (EMPA) were performed on the instrument Cameca SX-50, in the Joint Laboratory of Electron Microscopy and Microanalysis of the Masaryk University and the Czech Geological Survey (Brno, Czech Republic) by analysts R. Čopjaková and R. Škoda. Wavelength-dispersion mode with a beam diameter of 4-5 $\mu \mathrm{m}$, an accelerating potential of $15 \mathrm{kV}$ and sample current of $20 \mathrm{nA}$ were used for $\mathrm{Si}, \mathrm{Al}, \mathrm{Ti}, \mathrm{Fe}, \mathrm{Mn}, \mathrm{Mg}$, $\mathrm{Ca}, \mathrm{Na}$ and $\mathrm{K}$. Higher current of $40 \mathrm{nA}$ was employed for $\mathrm{Zn}, \mathrm{F}$ and $\mathrm{P}$; counting time was $20 \mathrm{~s}$ for all elements. The following standards were used (K X-ray lines): diopside $(\mathrm{Si}, \mathrm{Ca})$, kyanite $(\mathrm{Al})$, fayalite $(\mathrm{Fe})$, rutile $(\mathrm{Ti})$, pyrope $(\mathrm{Mg})$, spessartine $(\mathrm{Mn})$, albite $(\mathrm{Na})$, orthoclase $(\mathrm{K})$, fluorapatite $(\mathrm{P}, \mathrm{F})$ and gahnite $(\mathrm{Zn})$.
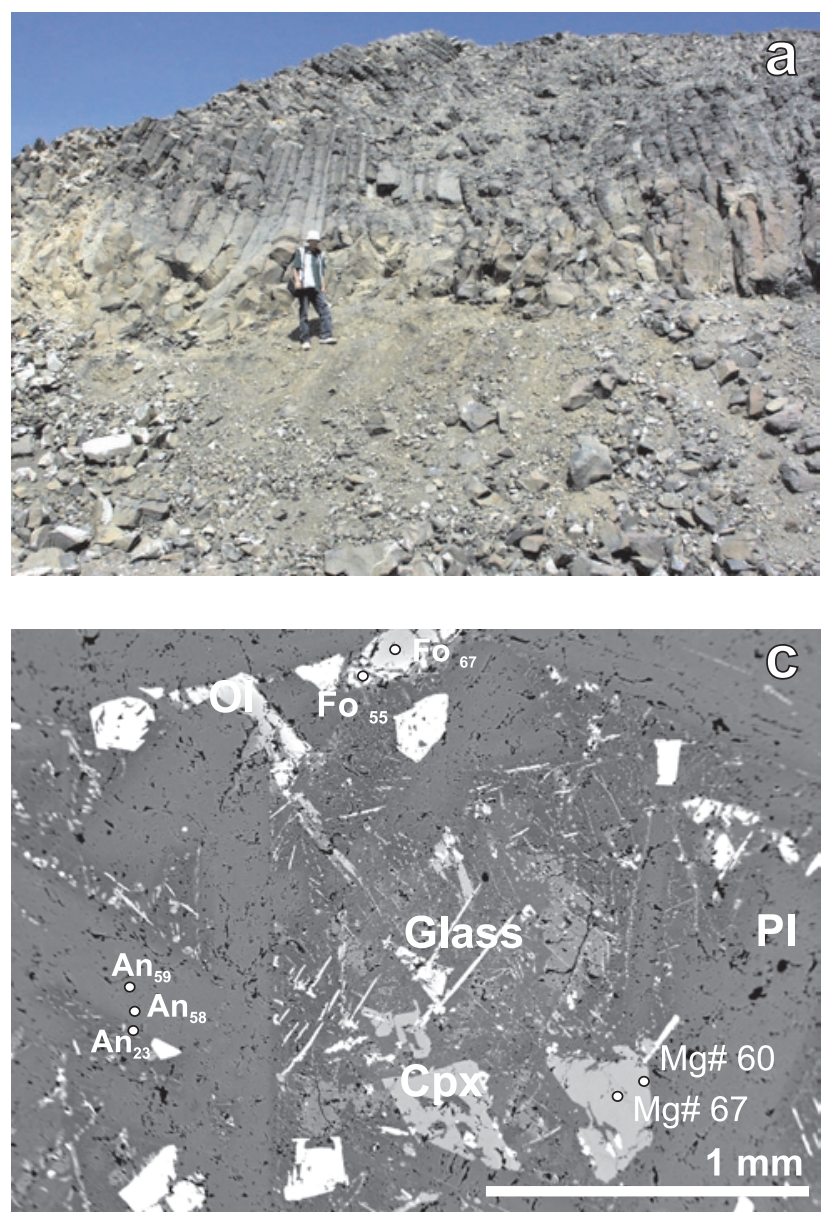

\section{Geology and petrology of volcanic rocks}

Cretaceous volcanic rocks in the Shiliin Nuruu are stratigraphically related to the uppermost part of the Khulsan Gol Fm. Three groups of volcanic rocks were distinguished here according to volcanic character and petrography: 1 - massive basalt to basaltic andesite lava sheets and sills; 2 - basaltic to trachyandesitic tuffs; 3 - volcanic breccias, lahars.

\subsection{Basalt to basaltic andesite}

Lava sheets and sills composed of massive basalt to basaltic andesite are the most common volcanic forms. At least three main lava flows alternate with siltstones, marlstones and sandstones in the studied area. Thickness of individual lava flows reaches up to $30 \mathrm{~m}$; the sills are up to $20 \mathrm{~m}$ thick. The basalts are massive, often with columnar jointing (Fig. 3a-b). The flows of basalt into
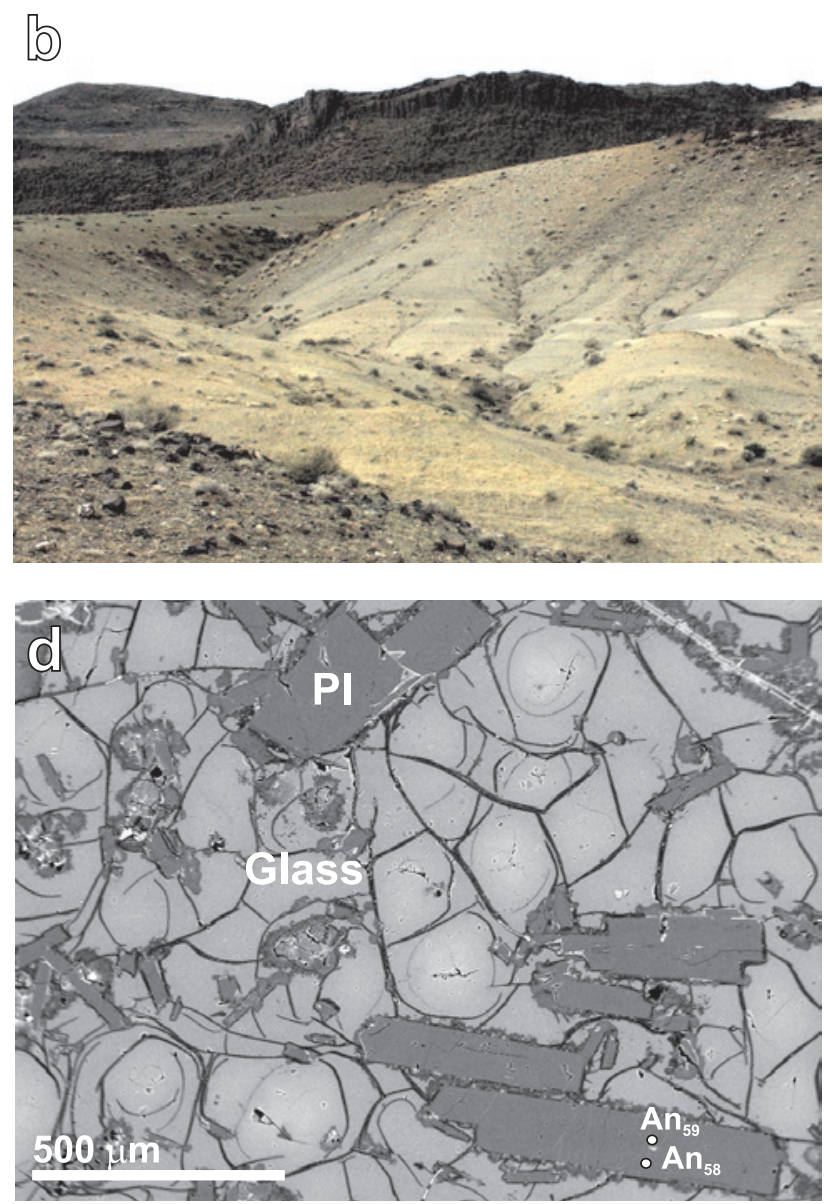

Fig. 3 Outcrop photographs (a-b), a BSE photo (c) and a photomicrograph (d) from Shiliin Nuruu area: a, b - basalt lava flows in hanging wall of sandstones of the Khulsan Gol Fm.; c - intersertal texture in the basalt. Interstices between plagioclase, pyroxene and olivine grains are filled by glass and secondary minerals; d - vitrophyric basalt; plagioclase xenocrysts set in glass matrix with perlitic cracking (An - anorthite component in plagioclase, $\mathrm{Fo}$ - forsterite component in olivine, $\mathrm{Mg} \#-$ atomic $100 \times \mathrm{Mg} /\left(\mathrm{Fe}^{2+}+\mathrm{Fe}^{3+}+\mathrm{Mn}+\mathrm{Mg}\right)$ in clinopyroxene $)$. 
water-rich sediments are documented by the disintegration of lavas into blocks, the occurrence of rare pillow lavas and the presence of marlstone tongues penetrating basalt flows. Flow textures with ropy crust are locally preserved in this type of basalts rich in fluids. They have the same petrographic composition as massive basalts but their matrix is finer and the abundance of devitrified volcanic glass therein greater. The amygdales and cavities up to $40 \mathrm{~cm}$ in size are empty or filled with calcite and quartz crystals, chlorite, chalcedony and agate. Zeolites and pyrite are subordinate minerals.

Basalts to basaltic andesites are dark grey to black, fine- to medium-grained rocks. The igneous textures are ophitic, intersertal or porphyritic with fine-grained ophitic to subtrachytic or intersertal matrix (Fig. 3c). The groundmass consists of plagioclase [45-60 mod. (modal mineral proportion) \%], interstitial glass ( $0-30 \mathrm{mod} . \%)$ and sometimes clinopyroxene ( $0-25 \mathrm{mod} . \%)$ and/or olivine $(0-10 \bmod . \%)$ and opaque minerals (up to
5 mod. \%). Some clinopyroxene phenocrysts are poikilitic enclosing plagioclase laths. Amphibole is a minor mineral. Hematite and Ti-magnetite as typical accessory phases are often partially maghemitized. Basalts with vitrophyric texture are present locally (Fig. 3d). In this case the brown glass with perlite-like cracking encloses long laths of plagioclase $(0.05-0.10 \mathrm{~mm})$ and euhedral opaque minerals. Minerals of the epidote and serpentinite groups, clay minerals and chlorite are secondary.

Typical olivine-clinopyroxene basaltic andesites with vitrophyric texture were studied using electron microprobe. Pyroxene phenocrysts and microlites are classified as augite (Morimoto et al. 1988). The clinopyroxenes are characterised by $\mathrm{Mg} \#$ (atomic $100 * \mathrm{Mg} /\left(\mathrm{Fe}^{2+}+\mathrm{Fe}^{3+}+\right.$ $\mathrm{Mn}+\mathrm{Mg})$ ) in the range 57-67 (Tab. 1). Clinopyroxene crystals also display a trend of decreasing $\mathrm{Mg}$ and $\mathrm{Ca}$ and increasing of $\mathrm{Fe}$ rimwards. Olivine phenocrysts and microlites are zoned (Tab. 1), with cores typically $\mathrm{Fo}_{46-57}$ and $\mathrm{Mg}$-rich rims $\left(\mathrm{Fo}_{63-70}\right)$. Plagioclase forms phenocrysts

Tab. 1 Representative chemical compositions of ferromagnesian minerals in the basalts [wt. \% and apfu based on $6 \mathrm{O}$ (pyroxene) and 4 O (olivine)].

\begin{tabular}{|c|c|c|c|c|c|c|}
\hline Sample & $\mathrm{C}(\mathrm{Px})$ & $\mathrm{C}(\mathrm{Px})$ & $\mathrm{E}(\mathrm{Px})$ & $\mathrm{E}(\mathrm{Px})$ & $\mathrm{E}(\mathrm{Ol})$ & $\mathrm{E}(\mathrm{Ol})$ \\
\hline Analysis & H1217/2 & H1217/5 & H0189/8 & H0189/2 & H0189/1 & $\mathrm{H} 0189 / 5$ \\
\hline $\mathrm{SiO}_{2}$ & 46.71 & 49.83 & 48.92 & 48.82 & 37.11 & 35.37 \\
\hline $\mathrm{TiO}_{2}$ & 2.31 & 0.94 & 1.47 & 1.75 & 0.03 & 0.11 \\
\hline $\mathrm{Al}_{2} \mathrm{O}_{3}$ & 3.72 & 1.31 & 2.67 & 2.65 & 0.04 & 0.02 \\
\hline $\mathrm{Cr}_{2} \mathrm{O}_{3}$ & 0.03 & 0.00 & 0.06 & 0.04 & 0.01 & 0.00 \\
\hline $\mathrm{NiO}$ & - & - & - & - & 0.13 & 0.06 \\
\hline $\mathrm{FeO}$ & 10.24 & 11.63 & 6.82 & 9.88 & 28.93 & 36.53 \\
\hline $\mathrm{Fe}_{2} \mathrm{O}_{3}$ & 3.91 & 2.94 & 4.47 & 2.41 & - & - \\
\hline $\mathrm{MnO}$ & 0.30 & 0.50 & 0.26 & 0.34 & 0.47 & 0.69 \\
\hline $\mathrm{MgO}$ & 10.66 & 12.26 & 12.87 & 12.51 & 33.06 & 27.12 \\
\hline $\mathrm{CaO}$ & 20.42 & 18.80 & 20.98 & 19.94 & 0.26 & 0.29 \\
\hline $\mathrm{Na}_{2} \mathrm{O}$ & 0.48 & 0.50 & 0.62 & 0.41 & - & - \\
\hline $\mathrm{K}_{2} \mathrm{O}$ & 0.00 & 0.01 & 0.01 & 0.01 & - & - \\
\hline Total & 98.78 & 98.73 & 99.15 & 98.75 & 100.03 & 99.75 \\
\hline $\mathrm{Si}^{4+}$ & 1.808 & 1.919 & 1.857 & 1.870 & 1.001 & 0.992 \\
\hline $\mathrm{Ti}^{4+}$ & 0.067 & 0.027 & 0.042 & 0.050 & 0.001 & 0.002 \\
\hline $\mathrm{Al}^{3+}$ & 0.170 & 0.060 & 0.119 & 0.120 & 0.001 & 0.001 \\
\hline $\mathrm{Cr}^{3+}$ & 0.001 & 0.000 & 0.002 & 0.001 & 0.000 & 0.000 \\
\hline $\mathrm{Ni}^{2+}$ & - & - & - & - & 0.003 & 0.001 \\
\hline $\mathrm{Fe}^{2+}$ & 0.331 & 0.375 & 0.216 & 0.316 & 0.652 & 0.857 \\
\hline $\mathrm{Fe}^{3+}$ & 0.114 & 0.085 & 0.128 & 0.069 & - & - \\
\hline $\mathrm{Mn}^{2+}$ & 0.010 & 0.016 & 0.008 & 0.011 & 0.011 & 0.016 \\
\hline $\mathrm{Mg}^{2+}$ & 0.615 & 0.704 & 0.728 & 0.714 & 1.329 & 1.135 \\
\hline $\mathrm{Ca}^{2+}$ & 0.847 & 0.776 & 0.853 & 0.818 & 0.008 & 0.009 \\
\hline $\mathrm{Na}^{+}$ & 0.036 & 0.037 & 0.046 & 0.030 & - & - \\
\hline $\mathrm{K}^{+}$ & 0.000 & 0.001 & 0.000 & 0.000 & - & - \\
\hline $\mathrm{Mg} \#$ & 57.5 & 59.7 & 67.4 & 64.3 & 66.7 & 56.5 \\
\hline
\end{tabular}


or glomerocrysts up to $2 \mathrm{~mm}$ across and small subhedral laths in the groundmass. The slightly oscillatory zoned plagioclase belongs mostly to labradorite $\left(\mathrm{An}_{58-59}\right)$; only narrow rims of the plagioclase laths could be classified as oligoclase $\left(\mathrm{An}_{23-28}\right)$. The content of the $\mathrm{SrO}$ is 0.2 wt. $\%$ and $\mathrm{K}_{2} \mathrm{O} \sim 0.2$ wt. $\%$ in the core and $0.9-1.0$ wt. $\%$ in the rim (Tab. 2). Interstitial glass of picrobasaltic composition $\left(\mathrm{SiO}_{2} \sim 44 \mathrm{wt} . \%\right)$ is partially replaced by chlorite and smectite. Plagioclase phenocrysts $\left(\mathrm{An}_{58-59}\right)$ in the basaltic andesite with vitrophyric texture are slightly oscillatory zoned and coexist with picrobasaltic glass $\left(\mathrm{SiO}_{2} \sim 44\right.$ wt. \%).

\subsection{Basaltic to trachyandesitic tuffs}

Basaltic tuffs and $a a$ lavas are subordinate members of the volcanic complex. They are made of massive or vesicular basalt fragments with oval volcanic bombs up to $50 \mathrm{~cm}$ in size. No gradation or preferential orientation of clasts was observed. Fine-grained ash tuffs are exposed only as rare, several $\mathrm{cm}$ thick layers and laminae in the siltstones.
Basaltic tuffs consist of four principal components: ash- to lapilli-size volcanic material, lithic clasts, altered matrix, volcanic bombs and lithic clasts (up to $50 \mathrm{~cm}$ ). The matrix includes fine-grained vitric ash, clay and calcite. The lapilli and crystal fragments are generally unaltered, only plagioclase fragments are rarely partially sericitized and carbonatized. The basalt bombs and clasts are predominantly massive to moderately vesicular. Petrographic character is very similar to massive basalts to basaltic andesites described above; the rocks are dominated by glass, plagioclase and/or clinopyroxene. Volcanic bombs have ophitic and subophitic textures in core and intersertal textures in the rim. Rare, small subangular lithic fragments are represented by siltstones and marlstones.

\subsection{Volcanic breccias, lahars}

Volcanic breccias, lahars and tuffaceous conglomerates with volcanic fragments of acid to intermediate composition are exposed as the uppermost member of the Khulsan Gol Fm. These rocks are restricted to the vicinity of the

Tab. 2 Representative plagioclase compositions (wt. \% and apfu based on 8 oxygens).

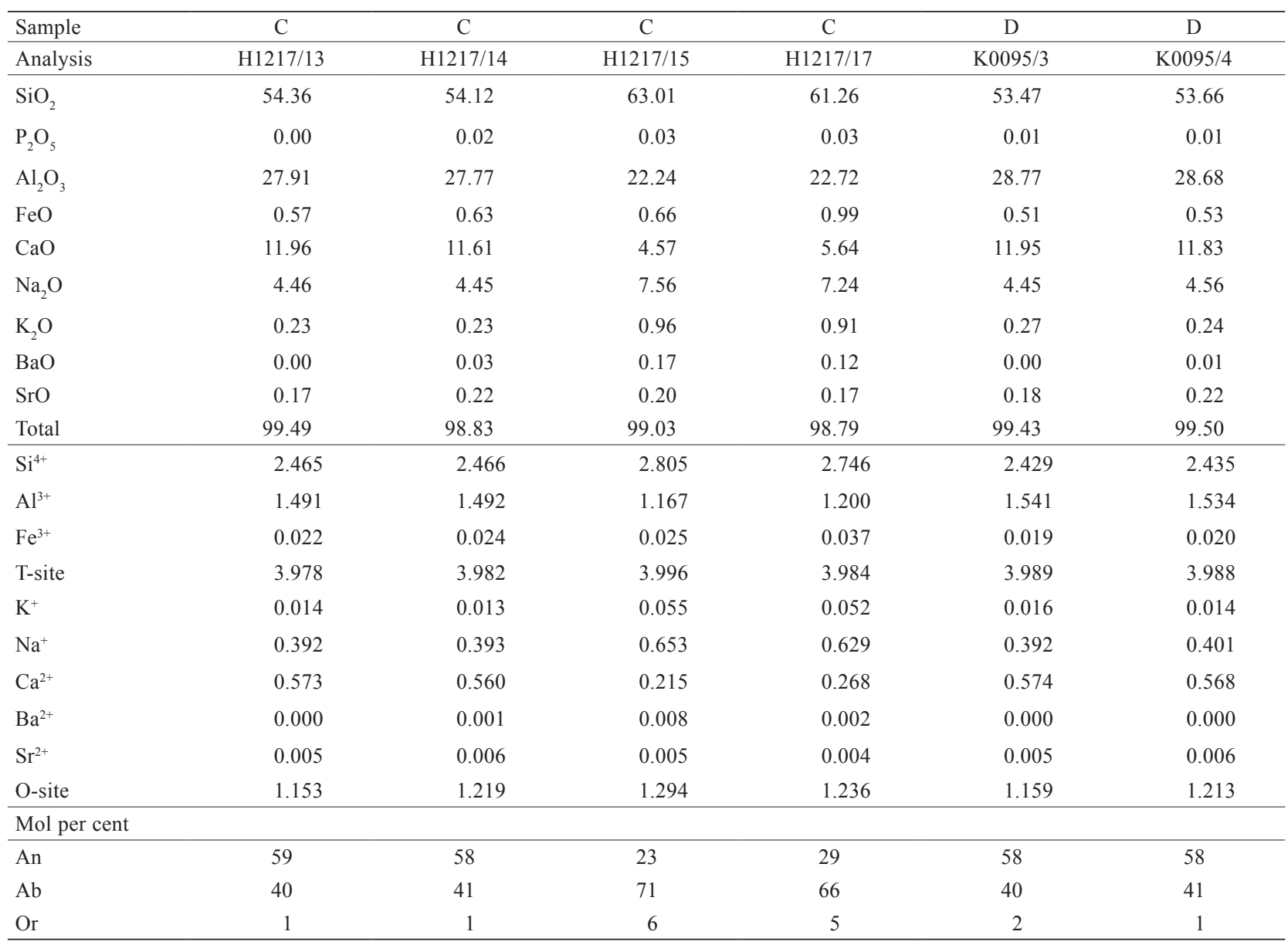


Arslan Khayrkhan Uul. Breccias form tabular bodies up to $100 \mathrm{~m}$ thick. These lack bedding and cover sediments of the Khulsan Gol Fm. (including the basaltic andesite sheets) as well as marlstones of the Anday Khudag Fm. The angular to subangular character of the fragments and the absence of bedding in the strongly consolidated breccia point to an origin related to debris flow and these rocks are described here as lahar.

The fragments are composed of red granites, various types of porphyries, rhyolites, dacites and rare andesites. They are angular to subangular with size reaching up to $2 \mathrm{~m}$. Matrix is reddish grey with tuffaceous ash- to lapillisize and consists of glass (rarely devitrified), feldspars, quartz and subordinate biotite with epidote. Matrix is locally chloritized, carbonatized and silicified. Dacite to rhyolite clasts are composed of quartz-feldspathic matrix often with glass and feldspar phenocrysts (of both K-feldspar and plagioclase). Minor minerals include muscovite, rare apatite, biotite and/or pyroxene. Chloritization of biotite and sericitization of plagioclase are common. Subangular to angular granite-like clasts are composed of equigranular fine- to medium-grained or porphyritic rocks with granitic texture. The main minerals are quartz (15-20 mod. \%), K-feldspar (35-40 mod. \%), plagioclase (30-35 mod. \%), biotite (3-5 mod. \%) and locally muscovite. Euhedral to subhedral plagioclases with oscillatory zoning are intensely sericitized in their cores. Subhedral $\mathrm{K}$-feldspar commonly contains microcline lamellae. Small biotite crystals frequently enclosed in feldspars are partially replaced by chlorite. Apatite, monazite, zircon and secondary epidote occur as accessory phases.

\section{Whole-rock geochemistry and Sr-Nd isotopic compositions}

The volcanic rocks of the Khulsan Gol Fm. show bimodal composition with strongly prevailing basic members. Basic to intermediate rocks are represented by nine, and acid rocks by a single analysed sample. Most of them are characterized by both major- and trace-element analyses; major-element data only are available from two samples (Tab. 3). Alteration played a substantial role in modification of the geochemistry in some lavas. Commonly is the degree of alteration assessed by the loss on ignition (LOI). For the purpose of determining the primary unaltered geochemical character, samples with $>2$ wt. $\%$ LOI were excluded from consideration, but are shown for comparison together with fresh samples in Fig 4. These samples indeed show a petrographic evidence for alteration such as the presence of newly-formed chlorite, iddingsite and sericite.

Tab. 3 Whole-rock geochemical data (major and minor elements) for volcanic rocks from the Khulsan Gol Fm. (wt. \%).

\begin{tabular}{|c|c|c|c|c|c|c|c|c|c|c|}
\hline Sample & A & B & $\mathrm{C}$ & $\mathrm{D}$ & $\mathrm{E}$ & $\mathrm{F}$ & G & $\mathrm{H}$ & $\mathrm{I}$ & $\mathrm{J}$ \\
\hline Analysis & D0735 & H0953 & H1217 & K0095 & H0189 & H0516 & H0542 & H0545 & H0079 & H0082 \\
\hline Rock & basaltic & basalt & basalt & basalt & basalt & basaltic & trachy- & porphyry & trachy- & basaltic \\
\hline & andesite & & & & & andesite & andesite & & andesite & andesite \\
\hline Type occur. & lava sheet & lava sheet & lava sheet & lava sheet & lava sheet & lava sheet & tuff & lahar & lava sheet & lava sheet \\
\hline E_coord. $\left({ }^{\circ}\right)$ & 98.958 & 98.762 & 98.493 & 98.475 & 98.517 & 98.381 & 98.518 & 98.525 & 98.356 & 98.391 \\
\hline N_coord. $\left({ }^{\circ}\right)$ & 45.356 & 45.408 & 45.003 & 45.5 & 45.43 & 45.484 & 45.547 & 45.559 & 45.474 & 45.499 \\
\hline Laboratories* & ACME & ACME & ACME & ACME & ACME & ACME & ACME & ACME & CGL & CGL \\
\hline $\mathrm{SiO}_{2}$ & 53.13 & 51.34 & 49.09 & 51.08 & 51.60 & 53.71 & 57.48 & 71.19 & 52.99 & 52.83 \\
\hline $\mathrm{Al}_{2} \mathrm{O}_{3}$ & 16.28 & 17.20 & 14.66 & 16.39 & 15.81 & 15.60 & 16.66 & 14.36 & 17.72 & 18.90 \\
\hline $\mathrm{Fe}_{2} \mathrm{O}_{3}$ & 9.73 & 10.70 & 13.20 & 10.23 & 10.68 & 9.04 & 7.64 & 2.45 & 4.30 & 2.90 \\
\hline $\mathrm{FeO}$ & - & - & - & - & - & - & - & - & 4.29 & 6.56 \\
\hline $\mathrm{MgO}$ & 5.24 & 5.19 & 4.11 & 4.60 & 5.95 & 3.76 & 2.51 & 0.54 & 3.86 & 4.45 \\
\hline $\mathrm{CaO}$ & 7.01 & 7.49 & 7.05 & 7.56 & 7.44 & 6.82 & 5.12 & 1.36 & 6.02 & 6.37 \\
\hline $\mathrm{Na}_{2} \mathrm{O}$ & 4.06 & 4.13 & 3.25 & 3.97 & 3.73 & 3.88 & 4.80 & 4.40 & 3.93 & 3.93 \\
\hline $\mathrm{K}_{2} \mathrm{O}$ & 1.03 & 0.98 & 1.93 & 0.60 & 0.70 & 0.80 & 1.81 & 4.05 & 2.02 & 0.88 \\
\hline $\mathrm{TiO}_{2}$ & 1.25 & 1.23 & 2.69 & 1.25 & 1.42 & 1.34 & 1.21 & 0.34 & 1.63 & 1.49 \\
\hline $\mathrm{P}_{2} \mathrm{O}_{5}$ & 0.29 & 0.28 & 1.56 & 0.33 & 0.46 & 0.61 & 0.51 & 0.09 & - & - \\
\hline $\mathrm{MnO}$ & 0.14 & 0.15 & 0.17 & 0.13 & 0.13 & 0.14 & 0.15 & 0.04 & 0.10 & 0.10 \\
\hline $\mathrm{Cr}_{2} \mathrm{O}_{3}$ & 0.02 & 0.01 & 0.01 & 0.01 & 0.02 & 0.01 & 0.00 & 0.00 & - & - \\
\hline LOI & 1.6 & 1.2 & 2.0 & 3.5 & 1.8 & 3.7 & 1.6 & 0.9 & 3.4 & 2.3 \\
\hline Total & 99.78 & 99.9 & 99.72 & 99.65 & 99.74 & 99.41 & 99.49 & 99.72 & 100.26 & 100.71 \\
\hline
\end{tabular}

* Laboratories: ACME = Acme Analytical Laboratories, Vancouver, Canada and CGL = Central Geological Laboratory in Ulaanbaatar, Mongolia 

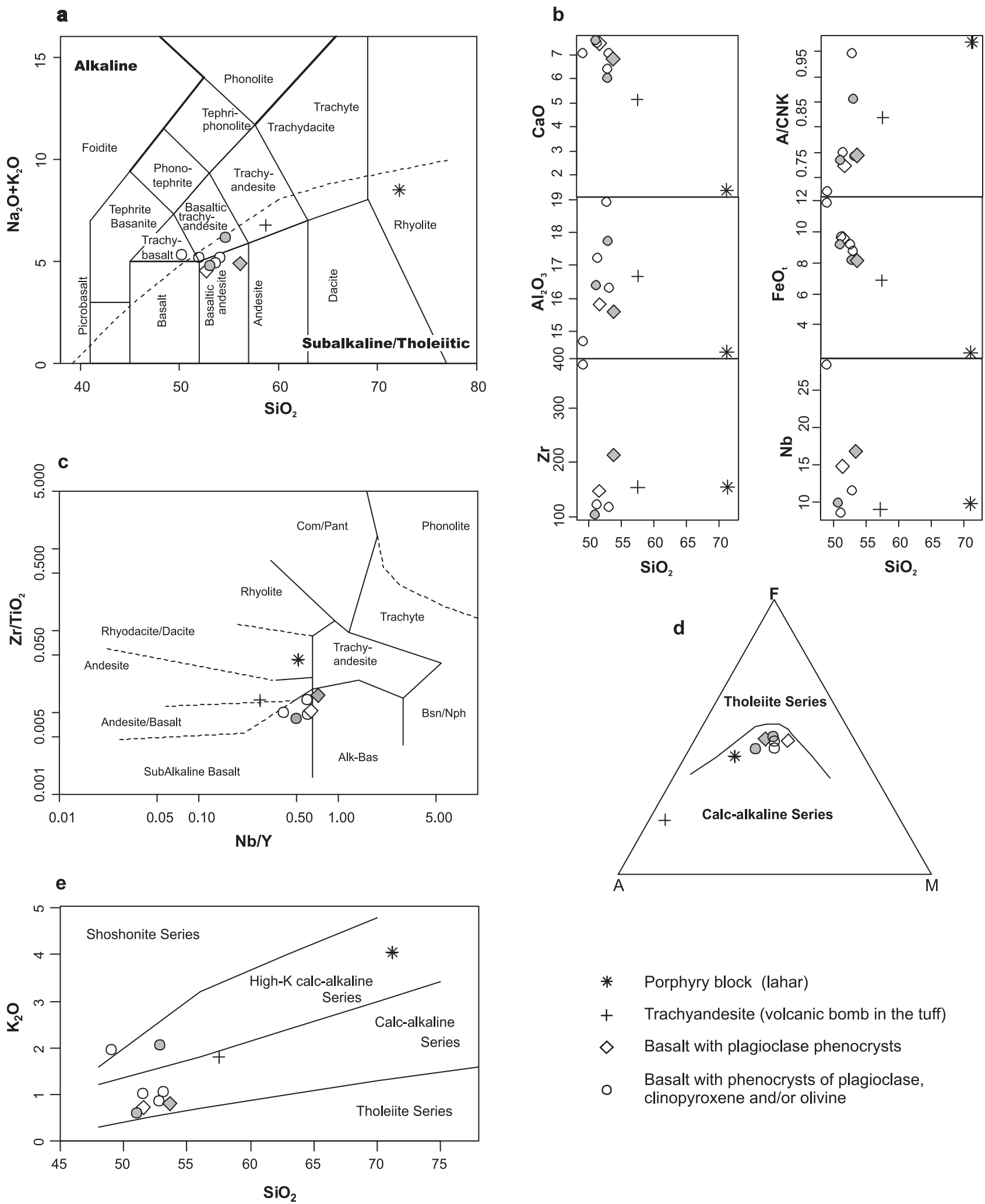

Fig. 4 Chemical composition of the volcanic rocks from the Khulsan Gol Fm.: a - Total alkali-silica diagram - TAS (Le Maitre et al. 2002); b - Variation diagrams $\mathrm{SiO}_{2}$ vs. $\mathrm{CaO}, \mathrm{A} / \mathrm{CNK}, \mathrm{Al}_{2} \mathrm{O}_{3}, \mathrm{FeO}_{\mathrm{t}}, \mathrm{Zr}$ and $\mathrm{Nb}, \mathbf{c}-\mathrm{Zr} / \mathrm{TiO}$ versus $\mathrm{Nb} / \mathrm{Y}$ diagram (Winchester and Floyd 1977), d $-\mathrm{AFM}$ diagram (Irvine and Baragar 1971), e $-\mathrm{SiO}_{2}-\mathrm{K}_{2} \mathrm{O}$ diagram (Peccerillo and Taylor 1976). Gray-filled symbols represent altered rocks with more than 2 wt. $\%$ of LOI. 

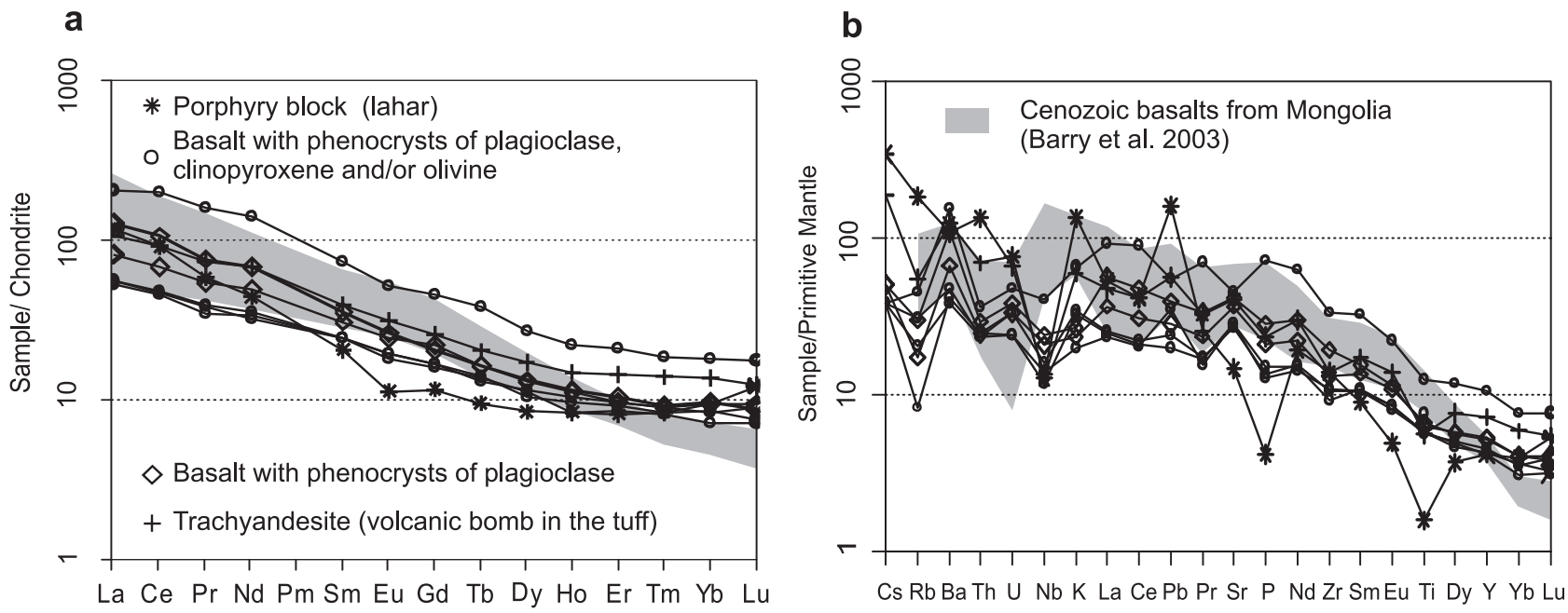

Fig. 5 Chemical composition of the volcanic rocks from the Khulsan Gol Fm.: a - Chondrite-normalized REE plot (Boynton 1984). b - Primitive-mantle normalized trace-element multielement diagram (Sun and McDonough 1989). Field for Cenozoic basalts from Mongolia (Barry et al. 2003 ) is shown for comparison.

The basic-intermediate rocks of the Khulsan Gol Fm. $\left(\mathrm{SiO}_{2}=49.0-57.5\right.$ wt. \%) contain moderate $\mathrm{MgO}$ concentrations $(2.5-6$ wt. \%). Variations of selected major and trace elements relative to $\mathrm{SiO}_{2}$ are shown in Fig. 4b.

In the TAS classification (Le Maitre et al. 2002, Fig. 4a) they correspond to subalkaline basaltic andesite or basaltic trachyandesite, one sample fits into field of alkaline trachybasalt and another to trachyandesite. In the $\mathrm{Zr} / \mathrm{TiO}_{2}$ versus $\mathrm{Nb} / \mathrm{Y}$ diagram (Winchester and Floyd 1977) the lavas correspond mainly to subalkaline basalt (Fig. 4c).
The AFM diagram (Irvine and Baragar 1971, Fig. 4d) characterises the majority of the samples as calc-alkaline. In the $\mathrm{SiO}_{2}-\mathrm{K}_{2} \mathrm{O}$ plot (Peccerillo and Taylor 1976, Fig. 4e), most rocks seem to belong to the normal calkalkaline series $\left(\mathrm{K}_{2} \mathrm{O}=0.6-2.0\right.$ wt. \%). The $\mathrm{K}_{2} \mathrm{O} / \mathrm{Na}_{2} \mathrm{O}$ ratios are usually low $(0.1-0.6)$.

Chondrite-normalized REE patterns are mutually comparable (Fig. 5a), with gently decreasing trend from LREE to HREE $\left(\mathrm{La}_{\mathrm{N}} / \mathrm{Yb}_{\mathrm{N}}=6-13\right)$ and no Eu anomalies. Individual patterns are subparallel, with differences in total REE contents (96-377 ppm).
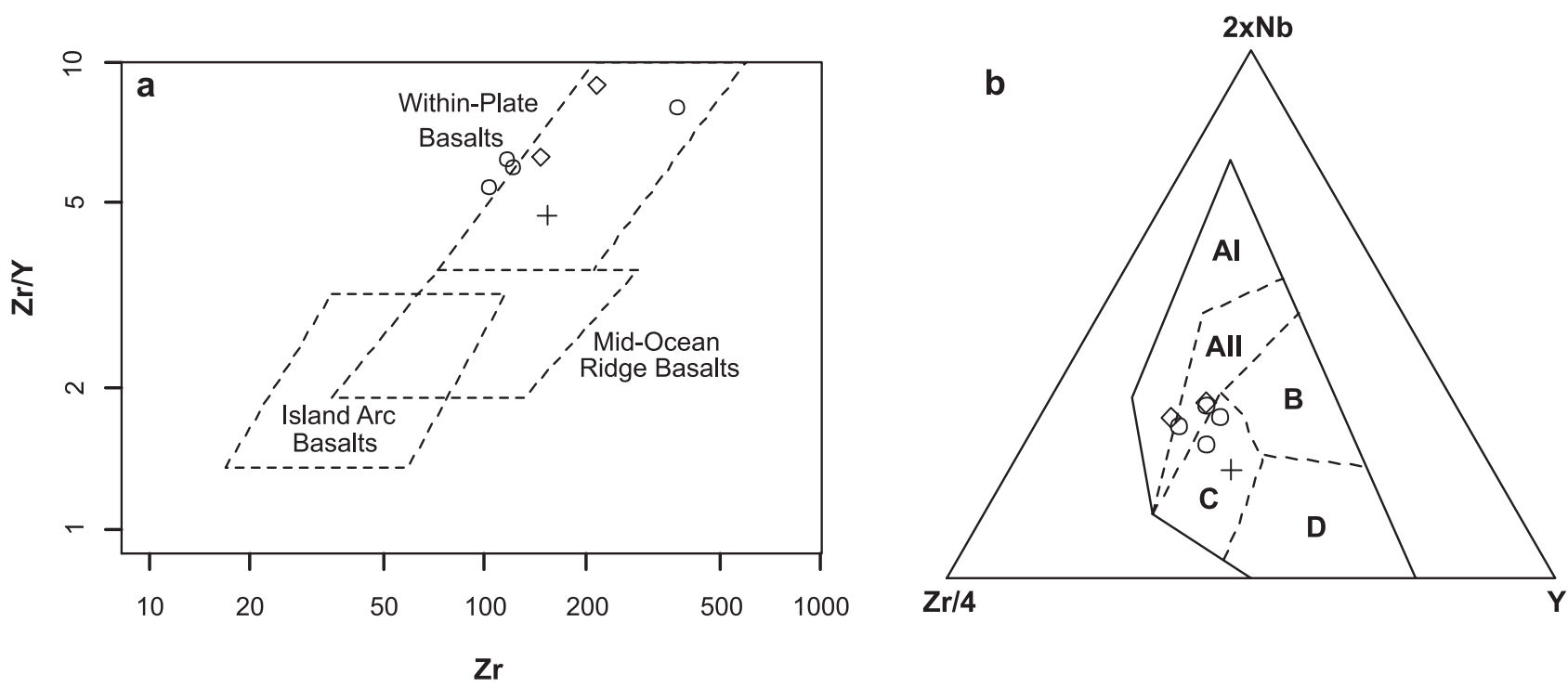

Fig. 6 Geotectonic discriminant diagrams: $\mathbf{a}-\mathrm{Zr}-\mathrm{Zr} / \mathrm{Y}$ classification plot (Pearce and Norry 1979) and $\mathbf{b}-$ discrimination diagram $\mathrm{Zr} / 4-2 \times \mathrm{Nb}-\mathrm{Y}$ (Meschede 1986); AI-AII = Within-Plate Alkaline Basalts, AII-C = Within-Plate Tholeiites, B = P-type Mid-Ocean Ridge Basalts, D = N-type Mid-Ocean Ridge Basalts, C-D = Volcanic Arc Basalts. Symbols as in Fig. 4. 
The primitive- mantle normalised spider diagram (Fig $5 b$ ) shows strong enrichment in LIL elements; negative anomalies in $\mathrm{Rb}$ and $\mathrm{Nb}$ are also characteristic. On the other hand, Ba forms strong positive anomalies. Rocks plot as within-plate basalts in the various geotectonic discrimination diagrams (e.g., Fig. 6a-b).

Acid sample of a porphyry block from volcanic breccia $\left(\mathrm{SiO}_{2}=71.2 \mathrm{wt}\right.$. \%) can be classified as rhyolite/ granite (Fig. 4a). Its $\mathrm{K}_{2} \mathrm{O}$ is high, fitting to high-K calcalkaline series (4.1 wt. \%), as is its $\mathrm{K}_{2} \mathrm{O} / \mathrm{Na}_{2} \mathrm{O}$ ratio (0.9). The REE pattern features a strong fractionation of LREE $\left(\mathrm{La}_{\mathrm{N}} / \mathrm{Yb}_{\mathrm{N}}=13\right)$ with a negative Eu anomaly $\left(\mathrm{Eu} / \mathrm{Eu}^{*}=\right.$ $0.7)$. Acid porphyry is, in comparison with more basic rocks, enriched in $\mathrm{Cs}, \mathrm{Rb}, \mathrm{Th}, \mathrm{U}, \mathrm{K}$, and $\mathrm{Pb}$ as well as strongly depleted in Ti and P.

The basaltic andesites have a less radiogenic strontium $\left({ }^{87} \mathrm{Sr} /{ }^{86} \mathrm{Sr}_{110}=0.7047\right.$ and 0.7049$)$ and more radiogenic neodymium $\left(\varepsilon_{110}^{N d}=+1.8\right.$ and +0.5$)$ than the porphyry block from the volcanic breccia $\left({ }^{87} \mathrm{Sr}^{86}{ }^{86} \mathrm{Sr}_{110}=0.7078\right.$ and $\left.\varepsilon_{110}^{N d}=-0.8\right)($ Tab. 4)

\section{Discussion}

The Mesozoic volcanites of the Khulsan Gol Fm. in the Shillin Nuruu area are represented by basaltic andesite, trachybasalt to trachyandesite lavas with subordinate tuffs and lahars. The relation with palaeontologically documented sediments points to its uppermost Early Cretaceous age (Aptian-Albian). The lavas were extruded subaerially, although also sills are locally present. The rare pillow lavas and the presence of vitrophyric basaltic glass document lava flows into subaqueous environment.

The fairly evolved composition of the basaltic rocks (i.e. low $\mathrm{MgO}, \mathrm{Ni}$ and $\mathrm{Cr}$ ) is far from being in equilib-

a

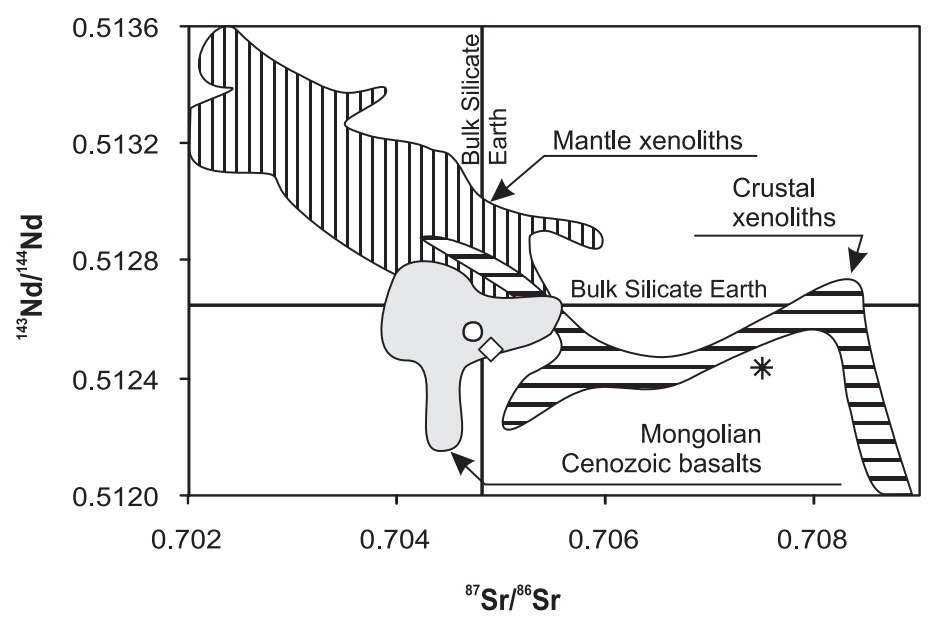

rium with mantle minerals. The decreasing $\mathrm{Ni}$ and $\mathrm{MgO}$ contents indicate fractionation of olivine. A positive correlation of $\mathrm{SiO}_{2}$ with $\mathrm{Al}_{2} \mathrm{O}_{3}$ and negative with $\mathrm{CaO}$ and $\mathrm{FeO}_{\mathrm{t}}$ suggest that clinopyroxene could have been an important fractionating phase in the evolution of the magma. The lithophile elements (e.g., $\mathrm{Pb}, \mathrm{K}$, and $\mathrm{Ba}$ ) are progressively enriched, while the HFSE tend to be increasingly depleted.

The role for crustal contamination can be assessed using trace elements. Studied basic-intermediate rocks show wide range of $\mathrm{Ce} / \mathrm{Pb}$ ratios (15-41) much more similar to mantle (ratios for most mantle compositions are $\sim 25$ and primitive mantle $\sim 9$; Hofmann et al. 1986) than to the crustal compositions $(\mathrm{Ce} / \mathrm{Pb}<5)$. On the other hand, $\mathrm{La} / \mathrm{Nb}$ ratios (1.5-3.7) are higher than in Cenozoic Mongolian basalts (Barry et al. 2003) (Fig. 7b), providing an evidence for crustal contamination $(\mathrm{La} / \mathrm{Nb} \sim 1.5$ for upper crust and $\sim 4.5$ lower crust; Taylor and McLennan 1985).

$\mathrm{The} \mathrm{Sr}$ and $\mathrm{Nd}$ isotope compositions of selected rock samples plot close to the Bulk Silicate Earth (Hart and Zindler 1986, Fig. 7a), which is a feature typical also of younger Mongolian basalts (Barry et al. 2003). For the basaltic samples, the time-integrated shift in the $\mathrm{Sr}$ isotopic value can be considered as negligible due to low $\mathrm{Rb} / \mathrm{Sr}$ values (0.01-0.03). The change in $\mathrm{Nd}$ isotopes is more significant, but still small enough to be within the limits typical for BSE rocks ( $\mathrm{Sm} / \mathrm{Nd}=0.17-0.24)$. Although the isotopic composition of the studied basaltic andesites does not show clear evidence for the crustal contamination, the influence of such process also cannot be excluded. As the isotopic composition of locally documented crustal xenoliths and of the studied acid porphyry are fairly primitive, the shift in isotopic composition resulting from reasonable extent of crustal contamination would be only limited.

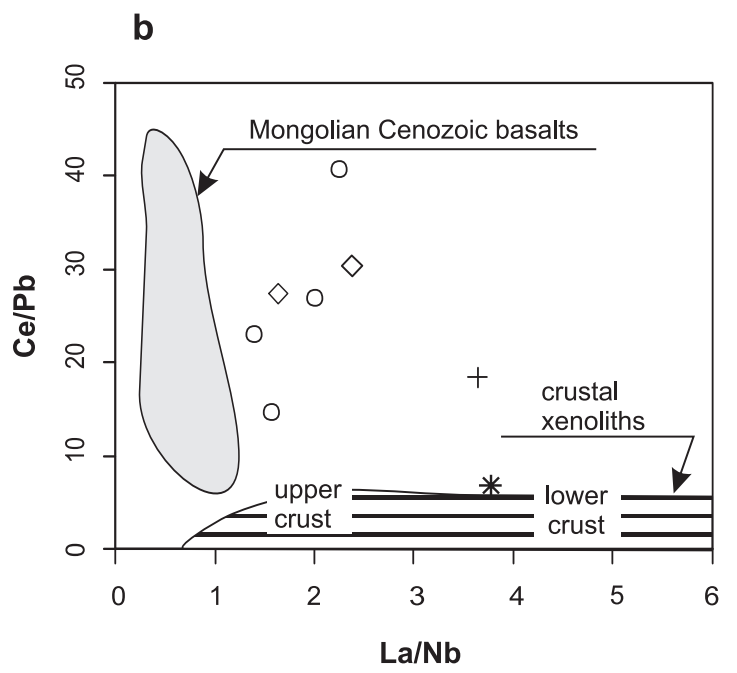

Fig. 7 Plots of ${ }^{143} \mathrm{Nd} /{ }^{144} \mathrm{Nd}$ versus ${ }^{87} \mathrm{Sr} /{ }^{86} \mathrm{Sr}$ (a) and $\mathrm{Ce} / \mathrm{Pb}$ versus $\mathrm{La} / \mathrm{Nb}$ plot (b) for Mesozoic volcanic rocks from Khulsan Gol Fm. Symbols as in Fig. 4. The fields for Mongolian Cenozoic basalts (gray), mantle (vertical hatching) and crustal (horizontal hatching) xenoliths are from Barry et al. (2003). Studied Cretaceous samples are age-corrected to $110 \mathrm{Ma}$ and Cenozoic samples of Barry et al. (2003) to $33 \mathrm{Ma}$. 
Tab. 4 Whole-rock trace-element chemical compositions (ppm) and Sr-Nd isotopic data for the volcanic rocks from the Khulsan Gol Fm.

\begin{tabular}{|c|c|c|c|c|c|c|c|c|}
\hline Sample & $\mathrm{A}$ & B & $\mathrm{C}$ & $\mathrm{D}$ & $\mathrm{E}$ & F & G & $\mathrm{H}$ \\
\hline Analysis & D0735 & H0953 & H1217 & K0095 & H0189 & H0516 & H0542 & H0545 \\
\hline $\mathrm{Sc}$ & 16 & 17 & 21 & 17 & 18 & 15 & 17 & 3 \\
\hline $\mathrm{Ba}$ & 329.3 & 266.2 & 1073.5 & 294.8 & 467.9 & 775.9 & 867.8 & 762.2 \\
\hline $\mathrm{Be}$ & 1 & 1 & 3 & 1 & 1 & 2 & 3 & 3 \\
\hline Co & 32.3 & 35.3 & 30.7 & 33.9 & 37.7 & 27.3 & 13.0 & 3.7 \\
\hline Cs & 0.3 & 0.3 & 0.3 & 0.3 & 0.4 & 0.4 & 1.5 & 2.7 \\
\hline $\mathrm{Ga}$ & 20.2 & 21.6 & 21.1 & 21.2 & 22.9 & 20.9 & 22.4 & 17.8 \\
\hline $\mathrm{Hf}$ & 3.3 & 3.0 & 8.7 & 2.5 & 3.6 & 5.4 & 4.7 & 4.9 \\
\hline $\mathrm{Nb}$ & 11.5 & 8.5 & 28.5 & 9.8 & 14.8 & 16.9 & 9.0 & 9.7 \\
\hline $\mathrm{Rb}$ & 19.8 & 12.9 & 28.6 & 5.2 & 11.0 & 18.9 & 35.0 & 117.6 \\
\hline $\mathrm{Sn}$ & 1 & 1 & 2 & 1 & 1 & 1 & 2 & 1 \\
\hline $\mathrm{Sr}$ & 560.1 & 599.6 & 941.9 & 599.7 & 772.1 & 871.3 & 857.3 & 308.5 \\
\hline $\mathrm{Ta}$ & 0.7 & 0.5 & 1.6 & 0.6 & 0.8 & 0.9 & 0.4 & 0.9 \\
\hline Th & 2.0 & 2.0 & 3.1 & 2.1 & 2.1 & 2.5 & 5.9 & 11.4 \\
\hline $\mathrm{U}$ & 0.7 & 0.5 & 1.0 & 0.5 & 0.7 & 0.8 & 1.6 & 1.4 \\
\hline V & 186 & 185 & 202 & 189 & 180 & 160 & 116 & 23 \\
\hline W & 0.5 & 0.9 & 0.5 & 0.4 & 0.4 & 0.4 & 0.5 & 0.6 \\
\hline $\mathrm{Zr}$ & 117.3 & 122.2 & 377.7 & 103.6 & 146.1 & 214.5 & 153.6 & 154.9 \\
\hline Y & 19.0 & 20.7 & 47.7 & 19.4 & 23.3 & 24.0 & 32.7 & 19.0 \\
\hline Mo & 0.7 & 0.6 & 0.8 & 1.0 & 0.7 & 0.7 & 1.2 & 0.7 \\
\hline $\mathrm{Cu}$ & 56.4 & 81.6 & 28.7 & 81.8 & 68.6 & 50.3 & 18.4 & 8.3 \\
\hline $\mathrm{Pb}$ & 1.7 & 1.4 & 3.9 & 2.5 & 2.0 & 2.8 & 4.0 & 11.5 \\
\hline $\mathrm{Zn}$ & 77 & 81 & 124 & 89 & 84 & 95 & 48 & 31 \\
\hline $\mathrm{Ni}$ & 82.0 & 71.2 & 25.4 & 80.6 & 89.5 & 63.5 & 7.7 & 3.9 \\
\hline $\mathrm{La}$ & 17.4 & 17.1 & 63.3 & 16.2 & 25.2 & 39.1 & 33.0 & 36.8 \\
\hline $\mathrm{Ce}$ & 39.0 & 37.6 & 158.9 & 36.5 & 54.7 & 85.2 & 73.8 & 73.6 \\
\hline $\operatorname{Pr}$ & 4.81 & 4.61 & 19.56 & 4.26 & 6.53 & 9.23 & 8.95 & 7.06 \\
\hline $\mathrm{Nd}$ & 21.1 & 19.3 & 84.3 & 20.2 & 29.7 & 40.8 & 40.8 & 26.4 \\
\hline $\mathrm{Sm}$ & 4.7 & 4.7 & 14.3 & 4.8 & 6.0 & 6.9 & 7.6 & 4.0 \\
\hline $\mathrm{Eu}$ & 1.34 & 1.44 & 3.74 & 1.43 & 1.80 & 1.91 & 2.30 & 0.83 \\
\hline Gd & 4.10 & 4.35 & 11.81 & 4.33 & 5.71 & 5.31 & 6.58 & 3.00 \\
\hline $\mathrm{Tb}$ & 0.65 & 0.62 & 1.81 & 0.66 & 0.78 & 0.77 & 0.96 & 0.45 \\
\hline Dy & 3.58 & 3.68 & 8.65 & 3.37 & 4.16 & 4.25 & 5.55 & 2.71 \\
\hline Но & 0.60 & 0.75 & 1.59 & 0.69 & 0.80 & 0.82 & 1.07 & 0.60 \\
\hline Er & 1.78 & 2.05 & 4.36 & 1.92 & 2.02 & 2.21 & 3.03 & 1.70 \\
\hline $\mathrm{Tm}$ & 0.26 & 0.29 & 0.60 & 0.27 & 0.29 & 0.30 & 0.45 & 0.27 \\
\hline $\mathrm{Yb}$ & 1.49 & 1.75 & 3.76 & 1.77 & 1.97 & 2.01 & 2.88 & 1.95 \\
\hline $\mathrm{Lu}$ & 0.23 & 0.29 & 0.56 & 0.24 & 0.30 & 0.28 & 0.40 & 0.39 \\
\hline $\mathrm{Ce} / \mathrm{Pb}$ & 22.94 & 26.86 & 40.74 & 14.60 & 27.35 & 30.43 & 18.45 & 6.40 \\
\hline $\mathrm{La} / \mathrm{Nb}$ & 1.51 & 2.01 & 2.22 & 1.65 & 1.70 & 2.31 & 3.67 & 3.79 \\
\hline${ }^{87} \mathrm{Rb} /{ }^{86} \mathrm{Sr}$ & - & - & - & 0.02509 & - & 0.06277 & - & 1.10351 \\
\hline${ }^{87} \mathrm{Sr} /{ }^{86} \mathrm{Sr}$ & - & - & - & 0.704776 & - & 0.705013 & - & 0.709540 \\
\hline 2 s.e. $\mathrm{Sr}$ & - & - & - & 0.000009 & - & 0.000013 & - & 0.000011 \\
\hline${ }^{147} \mathrm{Sm} /{ }^{144} \mathrm{Nd}$ & - & - & - & 0.14366 & - & 0.10224 & - & 0.09160 \\
\hline${ }^{143} \mathrm{Nd} /{ }^{144} \mathrm{Nd}$ & - & - & - & 0.512691 & - & 0.512595 & - & 0.512520 \\
\hline 2 s.e. $\mathrm{Nd}$ & - & - & - & 0.000006 & - & 0.000007 & - & 0.000008 \\
\hline$\left({ }^{87} \mathrm{Sr} /{ }^{86} \mathrm{Sr}\right)_{110}$ & - & - & - & 0.704737 & - & 0.704915 & - & 0.707815 \\
\hline$\left({ }^{143} \mathrm{Nd} /{ }^{144} \mathrm{Nd}\right)_{110}$ & - & - & - & 0.512588 & - & 0.512521 & - & 0.512454 \\
\hline$\varepsilon_{110}^{N d}$ & - & - & - & +1.78 & - & +0.49 & - & -0.83 \\
\hline
\end{tabular}


Crustal contamination can be documented also by the chemistry of porphyry clast from the lahar. This clast is very close to chemical composition of the adjacent Permian granites exposed in the footwall of the Mesozoic sequence. Their $\mathrm{Sr}-\mathrm{Nd}$ isotopic signature is also not very far from that of Bulk Earth; ${ }^{87} \mathrm{Sr}^{86}{ }^{86}{ }_{285}$ ratios are 0.7043 to 0.7048 , and $\varepsilon_{285}^{N d}$ values are +1.3 to +0.7 according Hanžl et al. (2007). The significant part of the lithic clasts in acid volcanic breccia thus may represent recycled material from the underlying Permian plutonic complex.

Widespread intraplate volcanism has occurred throughout Mongolia from Early Mesozoic through Miocene (Whitford-Stark 1987) up to Pleistocene-Holocene (Yarmolyuk and Kovalenko 2001) and can be subdivided into several stages.

The Early Mesozoic volcanic history was related with the largest Mesozoic rift structure in the northern Mongolia-western Transbaikalia (Vorontsov et al. 2007). The subalkaline to alkaline trachybasaltic andesites with subordinate basalts and trachytes documented by these authors were characterised by higher contents of $\mathrm{K}_{2} \mathrm{O}$ (2.38-3.85 wt. \%), Rb (30-101 ppm), Ba (842-2800 ppm), Th (4.1-12.8 ppm) and Pb (17.4-29.8 ppm) compared to the studied rock samples from the Shillin Nuruu area. Geochemical and isotopic data suggest that the basic rocks of the bimodal volcanic association are most likely products of melting of a geochemically variable mantle source (Vorontsov et al. 2007).

The Late Mesozoic-Cenozoic igneous rocks in the southern Mongolia adjacent to the Khangay Mts. are linked with a South Khangay hot spot (Yarmolyuk et al. 1994). Development and Cenozoic uplift of the Mongolian Plateau represented by Khentey and Khangay domes as well as basin and range topography are related to interaction of a mantle plume with the overlying lithosphere (Windley and Allen 1993). The several stages in development of the Khangay Mts. region were recognized (Yarmolyuk and Kovalenko 2001). The Late Jurassic period was represented by highly alkaline rocks and corresponded with the formation of the Khangay igneous province. Early Cretaceous stage was characterised by subalkaline basalts followed by acid rocks. At the Early Cretaceous stage (118-105 Ma), subalkaline basalts to andesitic basalts were dominant.

Geochemical and isotopic data indicate close relationship of samples studied in course of the present work with Early Cretaceous trachybasalts and trachybasaltic andesites in the eastern part of the Gobi-Altay rift zone in the Arts-Bogd area (Samoilov et al. 1998). These basic rocks $\left(\mathrm{Na}_{2} \mathrm{O}+\mathrm{K}_{2} \mathrm{O}=6-9\right.$ wt. \%) show isotopic composition $\left({ }^{87} \mathrm{Sr}^{286} \mathrm{Sr}_{130}=0.7049-0.7059\right)$ similar to the studied rocks from the Shillin Nuruu area. Chondrite-normalized REE patterns display analogous trends $\left(\mathrm{La}_{\mathrm{N}} / \mathrm{Yb}_{\mathrm{N}}=11-19\right)$ with no Eu anomalies. The total REE contents (221-498 ppm) are slightly higher than in basic rocks from the Shillin Nuruu area. The evolution of basaltic magmatism in the Gobi-Altay rift was related to the Khangay mantle hotspot (Samoilov et al. 1998). High heat flow, rifting and magmatism in the central part of Mongolia during the Late Mesozoic and Cenozoic times were presumably associated with this diapiric upwelling of a mantle asthenosphere (Windley and Allen 1993).

On the other hand, according to Barry et al. (2003), Cenozoic volcanism in Mongolia belongs to a large igneous province extending from NE China to Lake Baikal. Alkaline to calc-alkaline basaltic to trachyandesitic volcanic rocks $\left(\mathrm{K}_{2} \mathrm{O}=1.8-4.1 \mathrm{wt}\right.$ \%), form numerous small volcanic complexes distributed mainly throughout the central Mongolia. Chondrite-normalised REE patterns are very similar to those shown in Fig. 5b except for slight depletion in the $\mathrm{Tm}, \mathrm{Yb}$ and $\mathrm{Lu}$. The $\mathrm{Sr}-\mathrm{Nd}$ isotopic compositions of the studied samples resemble the Mongolian Cenozoic basalts (Fig. 7a), whose genesis was explained by partial melting of metasomatically-enriched lower lithospheric mantle (Barry et al. 2003).

The spatial relationship and geochemical similarity with the younger Cenozoic basalts in Mongolia suggests that the volcanites in the Shiliin Nuruu area could have been also associated with extension and thinning of the lithosphere along eastern margin of the Euroasian plate in the eastern China (Northrup et al. 1995). Calc-alkaline magmatism is common in this geotectonic environment (e.g. Hawkesworth et al. 1995). However, Liu et al. (2004) suggested that both the Indo-Eurasian collision and subduction of the Pacific Plate played important roles in the Cenozoic rifting and volcanism. The evolution after Indo-Asian collision may have driven lateral extrusion of the mantle asthenosphere and lithospheric thinning. Lateral mantle flow would help to explain many features of the Khangay mantle plume, asthenospheric upwelling under eastern China and related magmatic activity including volcanism in the Shillin Nuruu area.

\section{Conclusions}

The evolution of the Mesozoic intracontinental basin in western Mongolia filled by continental sediments was accompanied by a volcanic activity. One of the extension-related structures was the Gobi-Altay rift, parts of which are preserved today only in sunken blocks along the northern slopes of the Gobi-Altay range. The western part of the Gobi-Altay rift is represented by a syncline in the area of the Shiliin Nuruu and smaller blocks surrounding the Khar Argalantyn Mts. The E-W oriented syncline is formed by the Upper Jurassic to Lower Cretaceous continental sediments. The extensional evolution of this basin culminated by huge volcanic activity in the Early Cretaceous. 
Bimodal volcanic sequence consists of basaltic lava sheets and small amounts of acid effusive rocks. The basaltic to andesitic lavas $\left(\mathrm{SiO}_{2}=49-58\right.$ wt. \%) extruded mainly subaerially, and only locally in a subaqueous environment. Volcanic rocks associated with continental rifting could have been related to the evolution of the socalled southern Khangay hot spot and reflect lithospheric thinning and extension. Variations in chemical composition reflect major role for fractional crystallization driven mainly by clinopyroxene and, to a lesser extent, olivine. The parental magma was presumably generated by melting of metasomatically enriched lower lithospheric and/or uppermost asthenospheric mantle. However trace-element and $\mathrm{Sr}-\mathrm{Nd}$ isotope compositions of some lavas provide an evidence for crustal contamination.

Volcanism in the Shiliin Nuruu area had a character distinct from that of the Early Mesozoic rift in the northern Mongolia, as indicated by within-plate geochemical features resembling the Cenozoic Mongolian basic volcanites. Geochemical and isotopic $(\mathrm{Sr}, \mathrm{Nd})$ similarity with Cenozoic volcanic rocks implies that bimodal volcanism of Shiliin Nuruu could have represented initial stages of this Cenozoic magmatic activity in Mongolia.

Acknowledgements. The fieldwork was undertaken during the project 'Geological survey of the Mongolian Altay on the scale 1:50,000' within the frame of the Program of the Development Cooperation Project of the Czech Republic. We are grateful to Mongolian staff of the expedition for participating in the fieldwork. We are indebted to J. Holák and Z. Novotný for technical backing of the geological survey.

Electronic supplementary material. The tables 3 and 4, as well as GPS coordinates of the studied samples, are available online at the Journal web site (http://dx.doi. org/10.3190/jgeosci.026).

\section{References}

Barry TL, Saunders AD, Kempton PD, Windley BF, PrinGle MS, DorjnamjaA D, SaAndar S (2003) Petrogenesis of Cenozoic basalts from Mongolia: evidence for the role of asthenospheric versus metasomatized lithospheric mantle sources. J Petrol 44: 55-91

BOYNTON WV (1984) Cosmochemistry of the rare earth elements: meteorite studies. In: HENDERSON P (ed) Rare Earth Element Geochemistry. Elsevier, Amsterdam, pp 63-114

Gilíková H, Budil P, Otava J, HanžL P, Buriánek D (2007) Mesozoic. In: HanžL P (ed) Geological survey of the Mongolian Altay at a scale of $1: 50,000$ (Zamtyn Nuruu - 50), Unpublished manuscript, Geological Information Centre, MRPAM, Ulaanbaatar
Graham SA, Hendrix MS, Johnson CL, Badamgarav D, Badarch G, Amory J, Porter M, Barsbold R, Webb LE (2001) Sedimentary record and tectonic implications of late Mesozoic rifting, southeast Mongolia. Geol Soc Am Bull 113: 1560-1579

Hanžl P, Aichler J, Bolormaa K, Byambasuren D, Budil P, Buriánek D, Hrdličková K, Erban V, Gerdes A, Gilíková H, Holák J, Janoušek V, Kosmák V, KrejČí Z, Malec J, Mašek D, Maštera L, Metelka V, Novotný Z, Otava J, Rejchrt M, RukavičKová L, Sidorinová T, Skácelová Z, TÁborský Z, Tsend-Ayush T, Valtr V, VEČEŘA J, VíT J (2007) Geological survey of the Mongolian Altay at a scale of $1: 50,000$ (Zamtyn Nuruu - 50), Unpublished manuscript, Geological Information Centre, MRPAM, Ulaanbaatar, pp 1-376

HART SR, ZindLER A (1986) In search for bulk-earth composition. Chem Geol 57: 247-267

Hawkesworth C, Turner S, Gallagher K, Hunter A, Bradshaw T, Rogers N (1995) Calc-alkaline magmatism, lithospheric thinning and extension in the Basin and Range. J Geophys Res 100: 271-286

Hendrix MS, Graham SS, Carroll AR, Sobel ER, Mc Knight CL, Schulein BJ, Wang Z (1992) Sedimentary record and climatic implications of recurrent deformation in the Tianshan: evidence from Mesozoic strata of the north Tarim, south Junggar and Turpan basins, northwest China. Geol Soc Am Bull 104: 53-79

Hendrix MS, Graham SA, Amory JY, Badarch G (1996) Noyon Uul syncline, southern Mongolia: Lower Mesozoic sedimentary record of the tectonic amalgamation of central Asia. Geol Soc Am Bull 108: 1256-1274

Hofmann AW, Jochum KP, Seufert M, White WM (1986) $\mathrm{Nb}$ and $\mathrm{Pb}$ in oceanic basalts: new constraints on mantle evolution. Earth Planet Sci Lett 79: 33-45

Irvine TN, BARAgAR WRA (1971) A guide to chemical classification of the common volcanic rocks. Can J Earth Sci 8: 253-248

Jacobsen SB, Wasserburg GJ (1980) Sm-Nd isotopic evolution of chondrites. Earth Planet Sci Lett 50: 139-155

JANOUŠEK V, FARROW CM, ERBAN V. (2006) Interpretation of whole-rock geochemical data in igneous geochemistry: introducing Geochemical Data Toolkit (GCDkit). J Petrol 47: 1255-1259

Kovalenko VI, Yarmolyuk VV, Bogatikov OA (1995) Magmatism, Geodynamics and Metallogeny of Central Asia. Miko Commercial Herald Publishers, Moscow, pp 1-272

Le Maitre RW, Streckeisen A, Zanettin B, Le Bas MJ, Bonin B, Bateman P, Bellieni G, Dudek A, Efremova S, Keller J, Lamere J, Sabine PA, Schmid R, Sorensen H, Woolley AR, (2002) Igneous Rocks: A Classification and Glossary of Terms, Recommendations of the International Union of Geological Sciences, Subcommission of 
the Systematics of Igneous Rocks. Cambridge University Press, Cambridge, pp 1-236

Liu M, Cui X, Liu F (2004) Cenozoic rifting and volcanism in eastern China: a mantle dynamic link to the Indo-Asian collision? Tectonophysics 393: 29-42

Lugmair GW, Marti K (1978) Lunar initial ${ }^{143} \mathrm{Nd} /{ }^{144} \mathrm{Nd}$ : differential evolution line of the lunar crust and mantle. Earth Planet Sci Lett 39: 349-357

MARTINSON GG (1982) Mesozoic lake's pools of Mongolia. Nauka, Leningrad, pp 1-210 (in Russian)

Meschede M (1986) A method discriminating between different types of mid-ocean ridge basalts and continental tholeiites with $\mathrm{Nb}-\mathrm{Zr}-\mathrm{Y}$ diagram. Chem Geol 56: 207-218

Mовімото N (1988) Nomenclature of pyroxenes. Mineral Mag 52: 535-550

Northrup CJ, Royden LH, Burchfiel BC (1995) Motion of the Pacific plate relative to Eurasia and its potential relation to Cenozoic extension along the eastern margin of Eurasia. Geology 23: 719-722

Pearce JA, Norry MJ (1979) Petrogenetic implications of $\mathrm{Ti}, \mathrm{Zr}, \mathrm{Y}$, and $\mathrm{Nb}$ variations in volcanic rocks. Contrib Mineral Petrol 69: 33-47

Peccerillo A, Taylor SR (1976) Geochemistry of Eocene calc-alkaline volcanic rocks from the Kastamonu area, northern Turkey. Contrib Mineral Petrol 68: 61-81

Rauzer AA, Zhanchiv DI, Golyakov VI, Ykhina IF, Ivanov IG, Tsukernik AB, Afonin VV, Smirnov IG, Bykhover VI, Kravtsev AV, BaAtarkhuYag A, Skoryukin Mi, Khodikov IV, Mantsev NV, OKaemov SV, Mischin VA, ENKHSAJKHAN T (1987) Report on results of geological mapping on scale 1:200,000 in the south-western part of Mongolian Altay in 1983-1983, Mongol. National. Rep. Tekhnoexport, Moscow, pp 1-352 (in Russian)

Richard P, Shimizu N, Allégre, CJ (1976) ${ }^{143} \mathrm{Nd} /{ }^{146} \mathrm{Nd}$, a natural tracer: an application to oceanic basalts. Earth Planet Sci Lett 31: 269-278

Samoilov VS, Yarmolyuk VV, Kovalenko VI, IVanov VG, Рокногснеnко YA (1998) Geochemical and isotopic characteristics and magma sources of the Early Cretaceous trachybasalts of the Gobi-Altai rift zone: an example of grabens in the Arts-Bogdo range. Geochem Int 12: 1203-1216

SinICA SM (1993) Jurassic and Lower Cretaceous of central Mongolia. In: The works combined Russian-
Mongolian paleontology expedition, vol 42. pp 1-236 (in Russian)

Steiger RH, Jäger E (1977) Subcommission on Geochronology; convention on the use of decay constants in geo- and cosmochronology. Earth Planet Sci Lett 36: 359-362

Sun SS, McDonough WF (1989) Chemical and isotopic systematics of oceanic basalts: implications for mantle composition and processes. In: SAUNDERS AD, NoRRY M (eds) Magmatism in Ocean Basins. Geol Soc London Spec Pub 42, pp 313-345

TaYlor SR, McLennan SM (1985) The Continental Crust: Its Composition and Evolution. Blackwell, Oxford, pp $1-312$

Vorontsov AA, Yarmolyuk VV, Lykhin DA, Dril SI, Tatarnikov SA, Sandimirova GP (2007) Magmatic sources and geodynamics of the Early Mesozoic Northern Mongolia-Western Transbaikalia rift zone. Petrology 15: $35-57$

Whitford-StARK JL (1987) A Survey of Cenozoic volcanism on mainland Asia. Geol Soc Am, Special Paper 213, pp 1-74

Winchester JA, Floyd PA (1977) Geochemical discrimination of different magma series and their differentiation products using immobile elements. Chem Geol 20: 325-343

Windley BF, Allen MB (1993) Mongolian plateau: evidence for a Late Cenozoic mantle plume under central Asia. Geology 21: 295-298

YANSHIN AL (1976) Map of Mesozoic and Cenozoic tectonics of the Mongolian People's Republic: U.S.S.R. Academia Sciences, Moscow, 4 sheets, scale $1: 1,5,000,000$

Yarmolyuk VV (1983) Late Paleozoic Volcanism of the Continental Rift Structures of Central Asia. Nauka, Moscow, pp 1-198 (in Russian)

YARMOLYUK VV (1986) Characteristics of structural position of continental rift structures in Mongolia. Izv Akad Nauk SSSR, Ser geol 9: 3-15 (in Russian)

Yarmolyuk VV, Kovalenko VI (2001) The Mesozoic-Cainozoic of Mongolia. In: Dergunov AB (ed) Tectonics, Magmatism, and Metallogeny of Mongolia, Taylor \& Francis Group, London, pp 203-244

Yarmolyuk VV, Ivanov VG, Kovalenko VI, Samoilov VS (1994) Dynamics of formation and magmatism of the Late Mesozoic-Cenozoic southern Khangai mantle hot spot, Mongolia. Geotektonika 5: 28-45 